\title{
Designing a Learning Game for the Deaf Children as an Educational Technology
}

\author{
Cristina Portugal \& Rita Maria de Souza Couto \\ Pontifical Catholic University of Rio de Janeiro, Brazil
}

\begin{abstract}
This article describes a development work whose focus was examining whether designing a game as an educational technology based on interdisciplinary dialogue between design and education can contribute to education of deaf children in learning a language. Through methods and techniques of design it was sought to identify how this area of knowledge can be part of the processes of teaching and learning in terms of developing learning materials to enhance the strategies of acquiring knowledge. The work was guided by the Multi-Tracks, which is a game to help the acquisition of a second language by deaf children. This game was developed in light of methods and techniques of design, under the Interdisciplinary Laboratory for Design/Education LIDE, Pontifical Catholic University of Rio de Janeiro, Brazil, in partnership with the National Institute of Education for the Deaf in Rio de Janeiro-INES/RJ. The development work was particularly interested in designing learning materials for deaf children by considering their special traits and dialogue with the surrounding reality. Considering that educational technology research in special education is rather weak, it was thought that this work may contribute to this interdisciplinary area.
\end{abstract}

Keywords: Interdisciplinary design; Educational technology; Learning games; Deaf Children; Special education

\section{Introduction}

This paper describes a development work related to teaching and learning situations via an interdisciplinary dialogue between design and education. Through methods and techniques of design it was sought to identify how this area of knowledge could contribute to the processes of teaching and learning at the setting of learning materials and enhance the process of acquiring knowledge. The work was guided by the Multi-Tracks, subject of this investigation, which is a game to help the acquisition of a second language by deaf children. This game was developed in the light of methods and techniques of design, under the Interdisciplinary Laboratory of Design/Education-LIDE, at the Pontifical Catholic University of Rio de Janeiro in Brazil, in partnership with the National Institute of Education for the Deaf in Rio de Janeiro-INES/RJ.

The article intends to present design as a field that can contribute effectively towards the creation of educational artifacts and cultural inventions, which are important aspects in human's cognitive development.

Design, according to Bonsiepe (2011), is the domain in which interaction between user and product is structured to facilitate effective actions. Fontoura (2002) says that design is an ample field that involves and to which different disciplines converge. It can be seen as an 
activity, as a process, or understanding in terms of its tangible results. It can also be perceived as a function of project management, project activity, conceptual activity, or even as a cultural phenomenon. It is viewed as a means to add value to things produced by humans and also as a vehicle for social and political change.

Design is an active process that influences society by creating its material culture. From this perspective, Frascara et al. (1997) points out that the world in which we live is more than the matter that has solidified as form and remained over time. Its form is defined by activity and action is its center. If design is conceived as oriented towards action, understood as active interaction as well as creative change, it will not focus on the object only as form. Quite the contrary, designers shall concern themselves with developing interactive process models in which object plays an indisputable core role as a means for action. According to this view, design relates to the totality of human interactions' concrete and intellectual spectrum, interaction among people, products and the world in which we live.

Starting with a vision open to inclusion, which characterizes the design area in general, this article and the work it describes assume that the design field has great potential for joint work with education, aimed at meeting contemporary society's new demands. It was precisely this understanding that led to the reflections found about the possibilities of an interdisciplinary dialogue between design and education as a main basis for the conceptualization of the "Design in Teaching-Learning Situations" line of investigation.

Using this definition of design as a field, which in Frascara et al. (1997) words "relates to the totality of human interaction's concrete and intellectual spectrum", one can be understand the path taken for carrying out this development work. The main purpose of the reported work is to investigate if a game developed by designers as an educational technology can create solutions for education of deaf children.

\section{Development Process}

In 2004 the LIDE team began to develop a development project entitled 'Multi-Tracks', a game to assist the acquisition of a second language by deaf children. The target audience for this project, which was carried out from 2004 to 2007, was deaf children enrolled in elementary school at the National Institute of Deaf Education of Rio de Janeiro-INES/RJ. Multi-Tracks was developed by designers but the participation of teachers and deaf students in the project had fundamental importance in the development of the game. This project, which had a clear interdisciplinary approach, received a "Scientists from Our State" scholarship from FAPERJ (2005-2007) and a "Productivity in Research" scholarship from CNPQ (2006-2009).

The actual object is a path game for tables or floors. The path is comprised of regular polygons; besides these elements, the Multi-Tracks game also has three sets of three scenarios each: Sugar Loaf, Fire Department and Zoo, action cards, bonus cards, command cards, support cards, pins and dice. The multimedia object is a game that consists of an outing in the city of Rio de Janeiro, initially starting at the three sets of three scenarios, each based on the actual objects. Each scenario has links to three tasks: a jig-saw puzzle, a connect-the-dots, and a word/image association puzzle.

The question that guided this project was: Can design methods and techniques applied to Design in Situations of Teaching-Learning promote the enhancement or enrichment of the 
teaching-learning process for children? We carried out this work starting with the idea that the job of a good designer within the scope of education, which is in large part seen as a project activity, at the same level as the one that leads to the configuration of maps, posters, books, visuals etc., is somewhat restrictive.

While discussing the related matters, our general objective became to ground for the Design in Situations of Teaching-Learning line of investigation to form the basis for discussions we intend to carry out.

The methodological aspects that served as a guide to this investigation, which had a qualitative bias, are shown below in the synthesis table for the development process. Each of these phases is related to an objective. Notwithstanding the presentation in phases, the whole process was founded on concomitant actions.

Table 1: Steps of the Development Process

\begin{tabular}{|c|c|c|c|c|}
\hline \multicolumn{5}{|c|}{ Research Process } \\
\hline $1^{\text {st }}$ Phase & $2^{\text {nd }}$ Phase & $3^{\text {rd }}$ Phase & $4^{\text {th }}$ Phase & $5^{\text {th }}$ Phase \\
\hline $\begin{array}{l}\text { Documental } \\
\text { research } \\
\text { Case Study }\end{array}$ & $\begin{array}{l}\text { Bibliographic } \\
\text { Research }\end{array}$ & $\begin{array}{l}\text { Bibliographic } \\
\text { Research }\end{array}$ & $\begin{array}{l}\text { Conceptualization } \\
\text { of the line of } \\
\text { research }\end{array}$ & Results \\
\hline $\begin{array}{l}\text { Documentation } \\
\text { and analysis of } \\
\text { the Multi-Tracks } \\
\text { game project } \\
\text { process }\end{array}$ & $\begin{array}{l}\text { Reading and } \\
\text { critical analysis of } \\
\text { texts }\end{array}$ & $\begin{array}{l}\text { Reading and } \\
\text { critical analysis of } \\
\text { texts }\end{array}$ & $\begin{array}{l}\text { Reading and } \\
\text { critical analysis of } \\
\text { texts }\end{array}$ & $\begin{array}{l}\text { Identification of } \\
\text { methodology for } \\
\text { Design in } \\
\text { Situations of } \\
\text { Teaching- } \\
\text { Learning }\end{array}$ \\
\hline $\begin{array}{l}\text { Operational } \\
\text { objective }\end{array}$ & $\begin{array}{l}\text { Operational } \\
\text { objective }\end{array}$ & $\begin{array}{l}\text { Operational } \\
\text { objective }\end{array}$ & General objective & $\begin{array}{l}\text { Operational } \\
\text { objective }\end{array}$ \\
\hline $\begin{array}{l}\text { A systematic } \\
\text { registry of the } \\
\text { history of Multi- } \\
\text { Tracks } \\
\text { configuration. } \\
\text { Multi-Tracks } \\
\text { proved when it } \\
\text { was used in the } \\
\text { classroom a rich } \\
\text { educational } \\
\text { material that } \\
\text { offers the teacher } \\
\text { several ways to } \\
\text { teach. }\end{array}$ & $\begin{array}{l}\text { Base and discuss } \\
\text { design questions } \\
\text { in light of } \\
\text { information and } \\
\text { communication } \\
\text { technologies, } \\
\text { addressing } \\
\text { cultural aspects, } \\
\text { language, image, } \\
\text { and construction } \\
\text { of meaning. }\end{array}$ & $\begin{array}{l}\text { Present studies on } \\
\text { design/education, } \\
\text { discussing issues } \\
\text { related to } \\
\text { teaching-learning, } \\
\text { games and visual } \\
\text { pedagogical } \\
\text { practices. } \\
\text { Discuss the design } \\
\text { in education line in } \\
\text { light of opinions } \\
\text { and reflections of } \\
\text { designers that } \\
\text { work in the } \\
\text { academic area. }\end{array}$ & $\begin{array}{l}\text { Ground the } \\
\text { design in } \\
\text { situations of } \\
\text { teaching-learning } \\
\text { line of } \\
\text { investigation. }\end{array}$ & $\begin{array}{l}\text { Contribute } \\
\text { towards the field } \\
\text { of design and of } \\
\text { education in } \\
\text { creating } \\
\text { subsidies for } \\
\text { planning } \\
\text { educational } \\
\text { materials and for } \\
\text { improving } \\
\text { standards of } \\
\text { education, } \\
\text { making learning } \\
\text { more productive } \\
\text { and interactive. }\end{array}$ \\
\hline
\end{tabular}


A part of the registry of the Multi-Tracks configuration (the graphic representation of LIBRAS for the Multi-Tracks Game) and the issues related to teaching and learning, which correspond to the fourth phase of the project, will be presented visually in this paper.

\section{Graphic Representation of LIBRAS for the Multi-Tracks Game}

The entire project of the Multi-Tracks Game has been through a long investigation on visual language based on the work of several authors who address issues of design (Lupton \& Phillips, 2009; Mitchell, 2005) and authors who address issues about deaf (Sacks, 1999) to be used on the scenarios, cards etc. However, in order to demonstrate the role that the design plays in Situations of Teaching and Learning, the illustration process of LIBRAS of the Multi-Tracks Game project will be presented in this article since it resulted in the development of a new graphical language to represent this language.

With the progress of the work, the cards with verbs, adjectives and pronouns would present a graphical representation of the Brazilian Language of Signs - LIBRAS and the referred word written in Portuguese. For the other grammatical classes we chose to stimulate the association of other languages - such as drawings, photographs, illustrations - with the Portuguese writing. To achieve these goals, we initiated the studies of the illustrations in LIBRAS. The first copies were made from photographs of students taken at the INES-RJ and from the search in the dictionary.

The big challenge in the graphical representation of LIBRAS says Portugal at al. (2011) comes from the existence of five parameters that make up the grammar of the LIBRAS. These are: (a) Configuration of hands (dactylology); (2) Place of articulation where the sign is located (in the body or away); (3) Movement: the form and the move that will be used (Some signs do not use movements); (4) Orientation: the proper way to fit the sign; (5) Facial and body expression: The facial expression must demonstrate the feeling according to the organization of the sentence. The body also presents posture according to the intended meaning.

These five parameters must be all in the same line and inserted in a context. If any of these parameters is removed, the sign will not come out properly. Based on these parameters, the LIBRAS illustrations of the Multi-Tracks Game were developed.

Faced with this challenge, we sought the author Wanderley (2004) who developed a work in which she discusses three main informational dimensions for graphic representation of actions: (1) the conceptual dimension, (2) the graphic dimension, and (3) the reader dimension. The parameters were presented through the identification and characterization of the conceptual information of the 'dynamic actions' (the elements that form or would form the idea), of the graphical information for the actions (the means and the graphic elements responsible for transmitting it graphically), and of the reader's effects (the reader's characteristics, influential in the perception of pictorial actions). These parameters were studied and applied in the process of illustration the LIBRAS.

The first step was to identify the verbs and adjectives which better suited the learning of the child beginning literacy. After selecting the verbs and adjectives which would be graphically represented in LIBRAS, a study was accomplished through dictionaries Portuguese-LIBRAS, 
through pictures and movies made by us about deaf children using the verbs and adjectives chosen to be graphically represented in LIBRAS. With this material, we started to outline the first illustrations and we introduced the first drafts to consultants specialized in LIBRAS ready to be validated and modified if necessary.

The construction process of the graphic language of LIBRAS is detailed in the works of Couto (2009) and Portugal (2009), and it was accompanied by two teaching consultants of INES/RJ, who are deaf and by a translator. The choice of a deaf consultant was extremely important to ensure that we were developing a language for the deaf. Moreover, the drawings were presented to the children of INES/RJ in order to identify the best way to represent them graphically.

Another important point for the illustrations was opting for infant characters according to the age of our target audience and considering the differences of the Brazilian people for the creation of the characters, seeking to bring the drawings the different colors of skin and hair, eye shapes etc.

It was noticed during the trials that the drawings of the characters representing in LIBRAS could not stick just to the use of hands, as mentioned earlier. Punctuations and intonations used in sentences in Portuguese are represented in LIBRAS through body and facial language. Some illustration studies were conducted to identify the best way to graphically represent body movements and expressions involved in this language. Below we present some studies of graphical representation of LIBRAS.
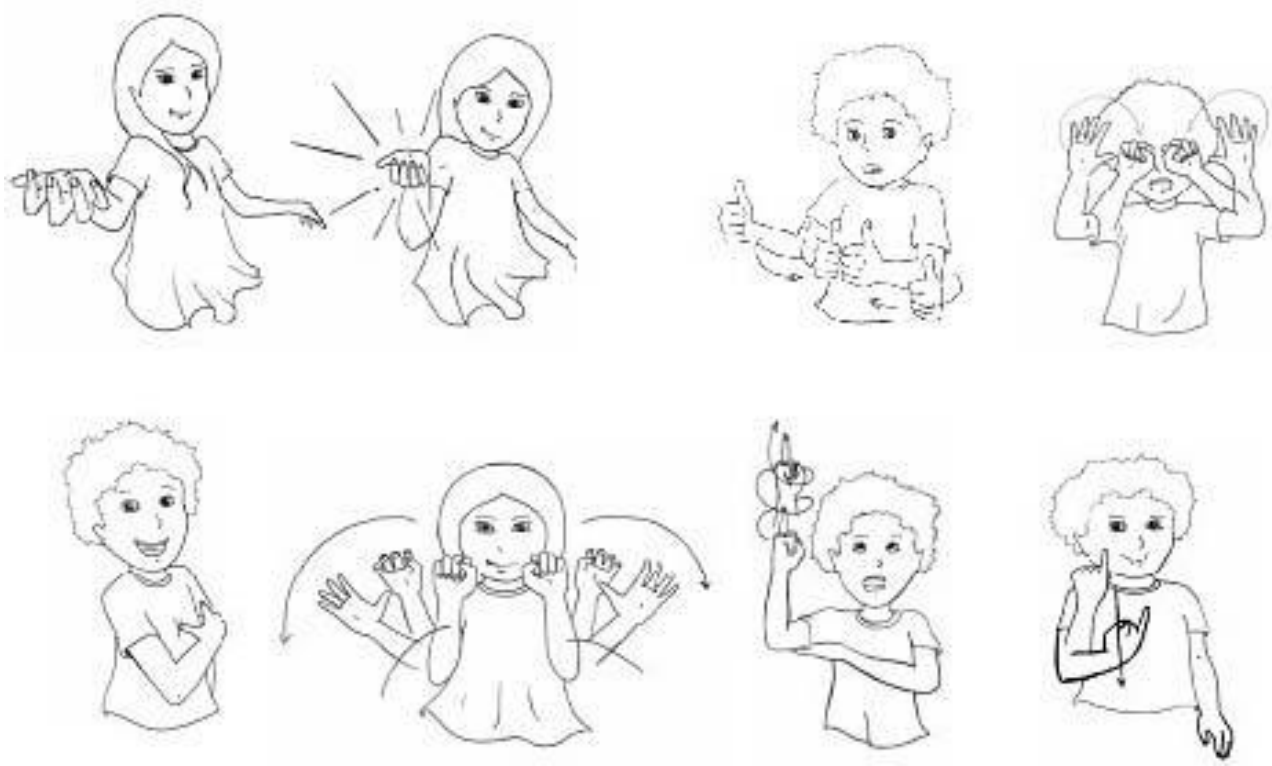

Figure 1. Studies of Illustration Aiming at Identifying the Best Way to Graphically Represent Body Movements and Expressions Involved in this Language

For applying the illustrations on the cards; once drawn free hand, the images were traced, colored on the computer, and applied. 

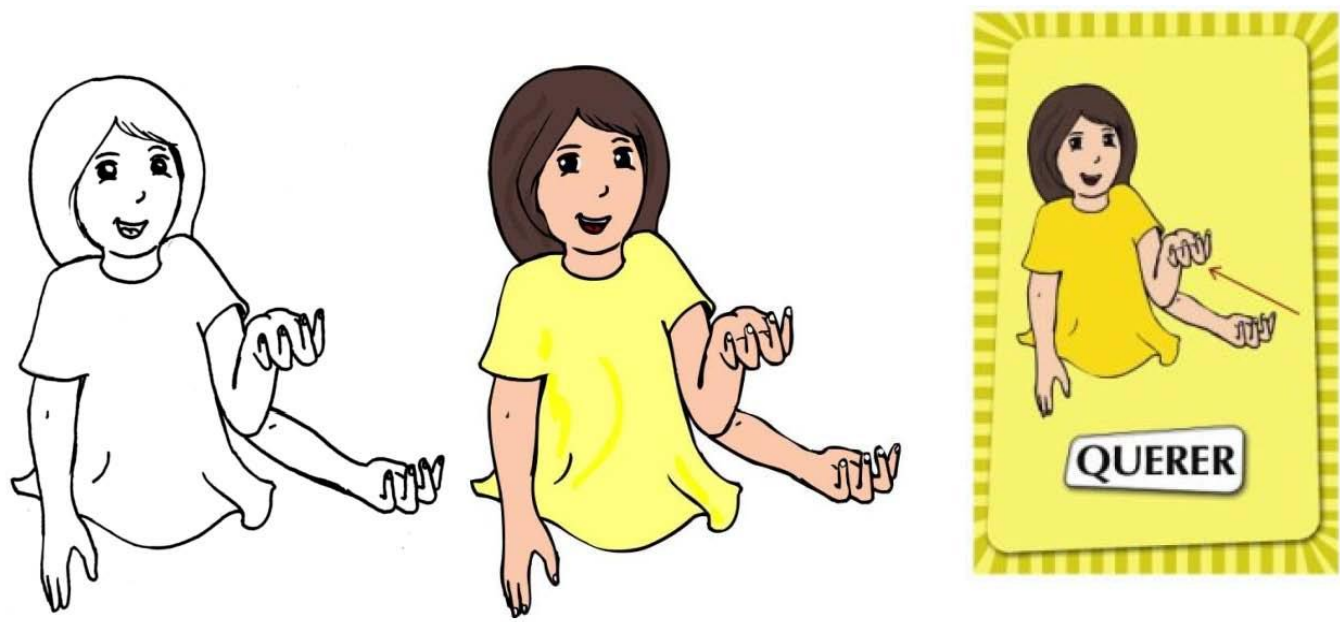

Figure 2. Application of the Illustrations on the Cards
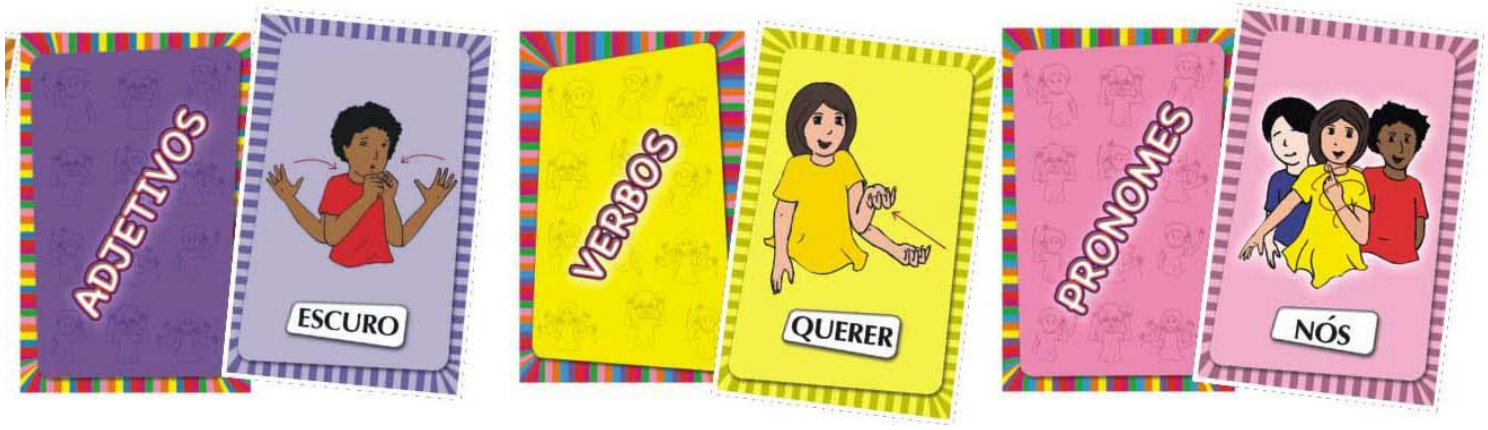

Figure 3. Examples of the Cards with a Didactic Repertoire

It took us more than one year researching and interacting with people who would be involved in the real situations of interaction, to reach the understanding of the importance of the active participation of the teacher as a builder as a co-author of the game.

\section{About the Multi-Tracks Game}

Based on several authors who address issues of interface design as Buxton (2007), Moggidge (2004), Spence (2007), Engelhardt (2002), Rollings and Morris (2004), the game multimedia was developed. Several prototypes were made until reaching version 1.0 of the game, which is part of this article. The final result was tested on different computers, on monitors of diverse sizes and in various operating systems, aimed at anticipating problems in running the game's CD. The multimedia Multi-Tracks game is now available online: http://www.multi-trilhas.com/.

\section{Game Components}

Version 1.0 of the game is comprised of scenarios that should be explored with the mouse and each presents different activities such as: connect-the dots, jig-saw puzzle, word/image association, drawing, painting etc. 


\section{Scenario}

With the intent of maintaining an identity of the multimedia game with the tangible game, the scenarios of the latter were redesigned to be compatible with digital media so that poorly dimensioned resources would not jeopardize access and make navigation difficult. The screens thus present three scenes of the Zoo, three of the Sugarloaf and three of the Fire Department Headquarters.

\section{Characters - Animation}

It was identified as the pertinence of using animated elements since animation is a multimedia resource that can also be used to represent information, and when well-used, it also becomes a resource for motivation.

\section{Sensitive Elements in the Scenarios - Interaction Style}

The direct manipulation interaction style was used. It comprised of actions based upon an analogy between the cursor and hand, the graphic representations and the objects of the domain. This direct manipulation interface style was chosen because it allows to act directly on the screen objects with the mouse (data of representations of domain objects) without the need for other commands.

In the Multi-Paths Game, the tasks are called from illustrations, which in turn necessarily lead to words in LIBRAS and written Portuguese. The words in Libras are presented by means of video (Images of the Libras Dictionary available on the INES site) and the words in Portuguese are shown written on the screen.

\section{Game Elements and How to Play}

1. Opening screen - Map of the city of Rio de Janeiro followed by screens with logos of PUCRio, INES, FAPERJ, CNPq and LIDE.

2. HOME Screen - Images of the characters and a board for writing the player's name. This information is also available on videos at Libras. Icons are available for the drawing activity screen, Libras dictionary, score; presentation of the game, exiting the game, choosing the background color for the screen. 


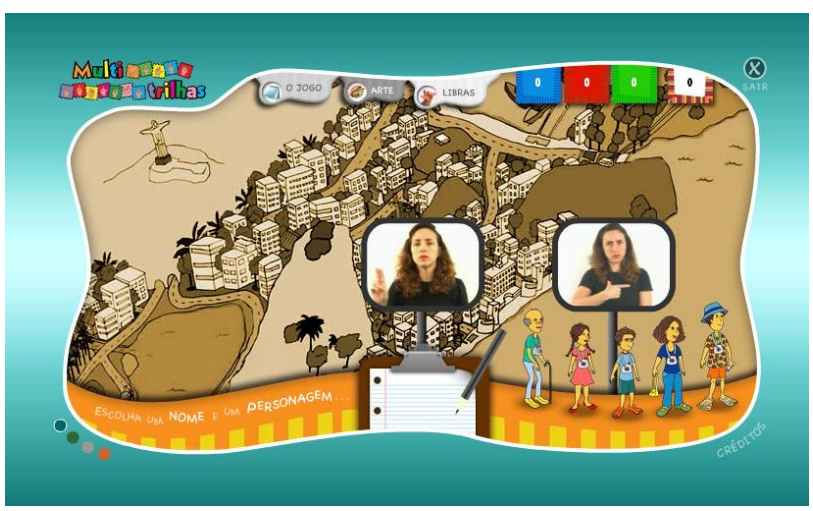

3. After choosing a character, the player goes to a screen where the 9 scenarios are available. These scenarios call up three activities each.

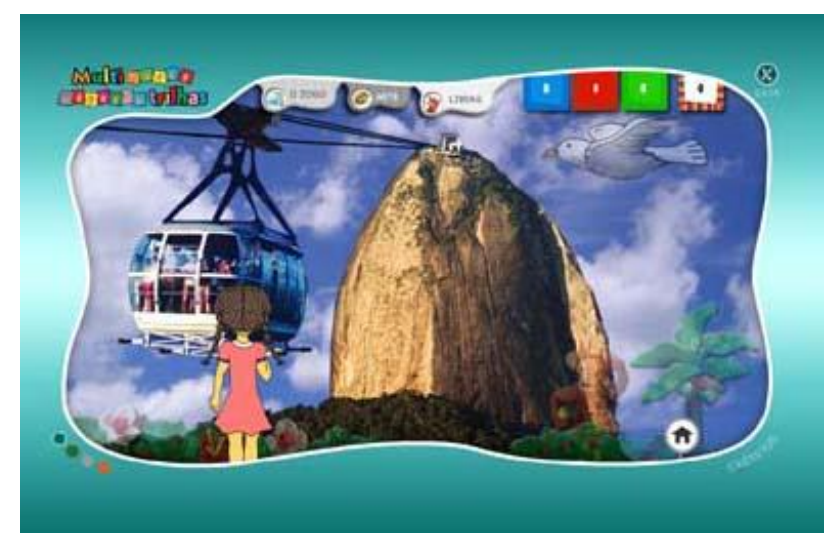

a) Make ghost images present in the scenario visible. These lead to screens where the player positions the image over the name representing the image, a word association activity. If correct, an animation of the character appears celebrating and automatically a screen with the score enters.

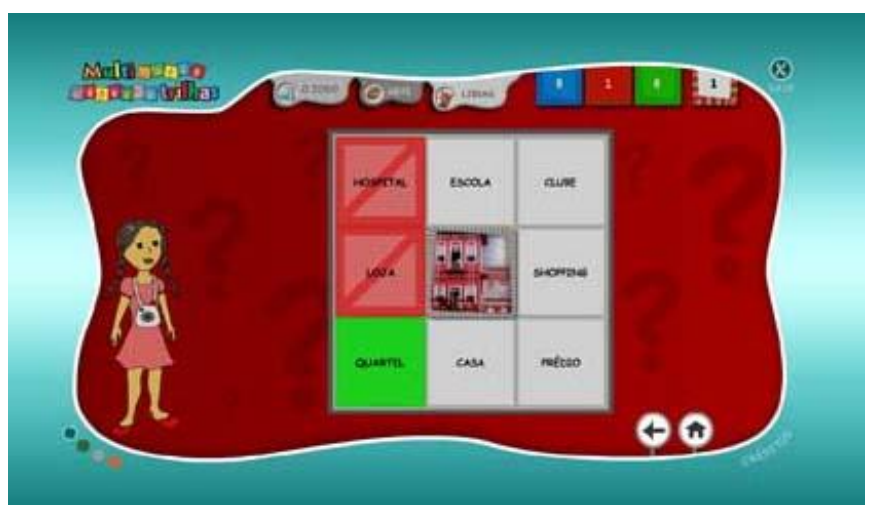

b) Make ghost images present in the scenario visible. These lead to screens where the player enters a numbered connect-the-dots activity. If correct, an animation of the character appears celebrating and automatically a screen with the score enters. 


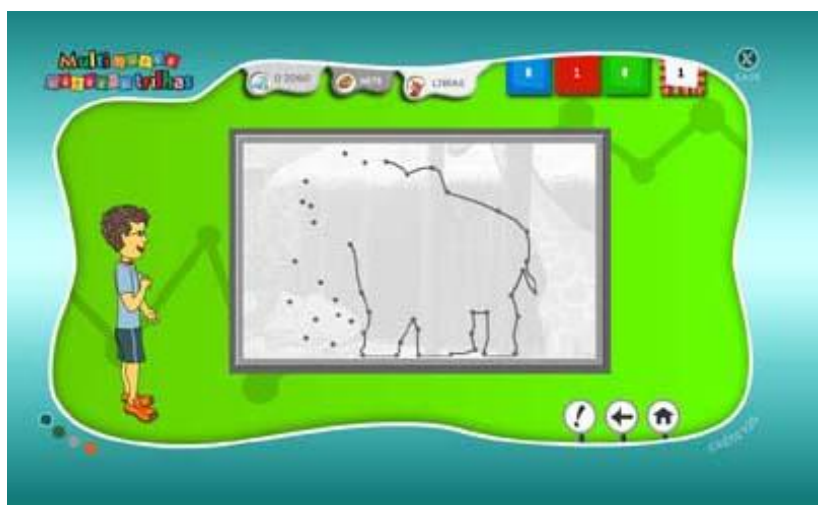

c) Make ghost images present in the scenario visible. These lead to screens where the player enters a jig-saw puzzle activity. If correct, an animation of the character appears celebrating and automatically a screen with the score enters.

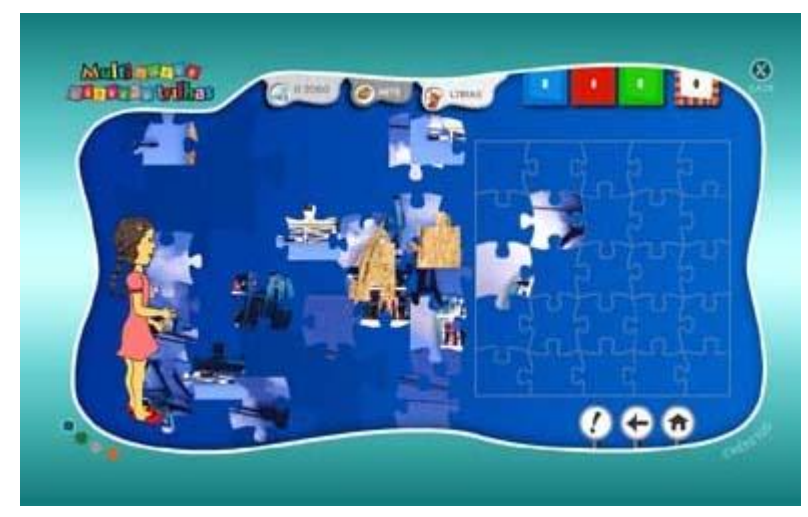

In every situation, the words being worked on in Libras (dictionary) and in written Portuguese appear.

Besides the various sensitive elements on the screen, where the player will be learning Portuguese and LIBRAS by clicking on them, the game also provides a free art activity. In this activity, it is possible to draw, paint, and create scenarios with characters, all with the assistance of the mouse. The following screen provides an example.

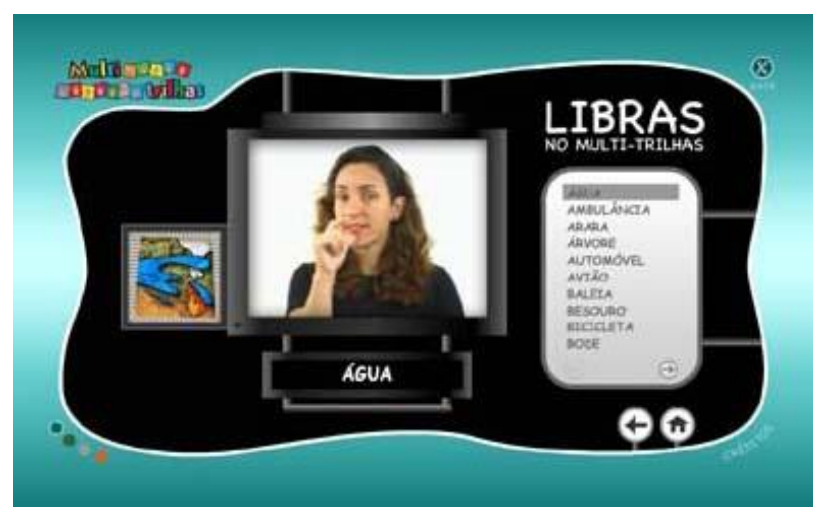




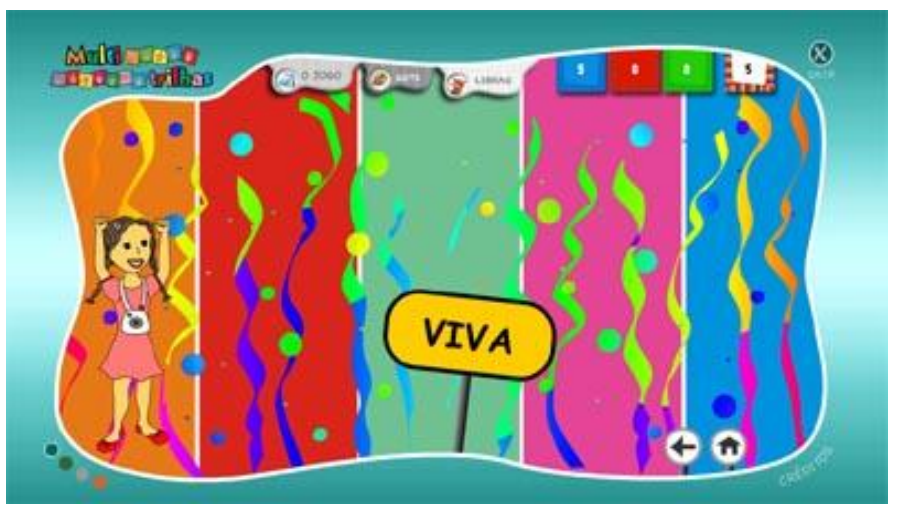

4. Congratulations screen - After finishing the five tasks in each scenario a celebration screen appears congratulating the player.

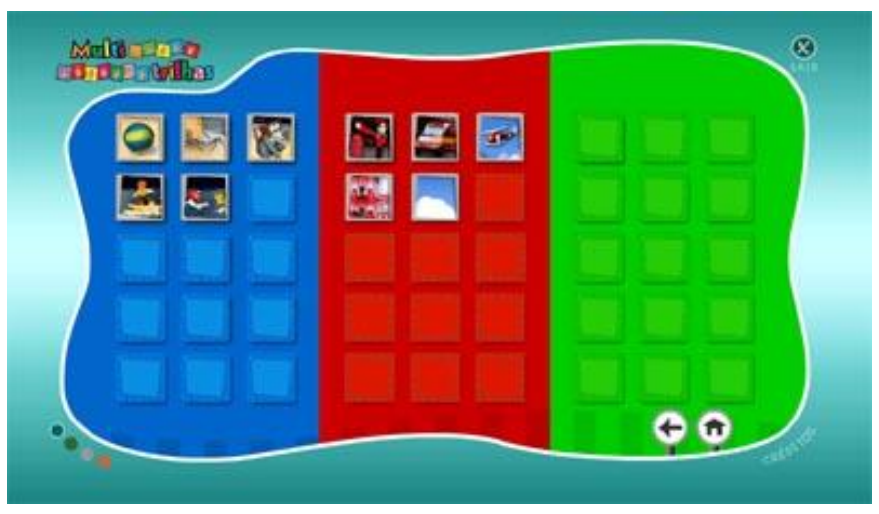

5. Score screens - These screens compute the player's points in all activities, except free art.

\section{Design Related Issues about Teaching-Learning}

We shall introduce Shulman's Model of Pedagogical Reasoning and Action (2008) as a subsidy for defining the Design in Situations of Teaching-Learning field in this article so the designer can understand how to operate in the Design/Education field.

Although this model is presented in a sequential manner, the author says this does not intend to represent a series of fixed phases, stages or steps. Many of the processes can occur simultaneously with the others. Some may not even happen during some teaching actions. Some may appear sectioned and others, on the contrary, defined in details. For example, it is possible that in teaching children some of these processes may be ignored or some may not be paid attention to in this model. However, a teacher should be able to demonstrate ability to participate in these processes. Faculty preparation must provide the students with forms of comprehension and with performance skills they require to move forward following an order and to carry out complete acts of pedagogy as represented in the model of pedagogical reasoning and action.

We introduce the model of pedagogical reasoning and action to present the Multi-Tracks game as an object of study that belongs to the Design in Situations of Teaching-Learning line of 
research because in order to use it the teacher must understand, transform, represent, select, adapt, teach, evaluate, reflect, and obtain new manners of comprehension which are the steps in Shulman's model of pedagogical reasoning and action.

We thus present the proposal for a Reasoning Model for analyzing projects within the scope of the Design in Situations of Teaching-Learning line of research applied to Multi-Paths, inspired on Shulman's model (2008).

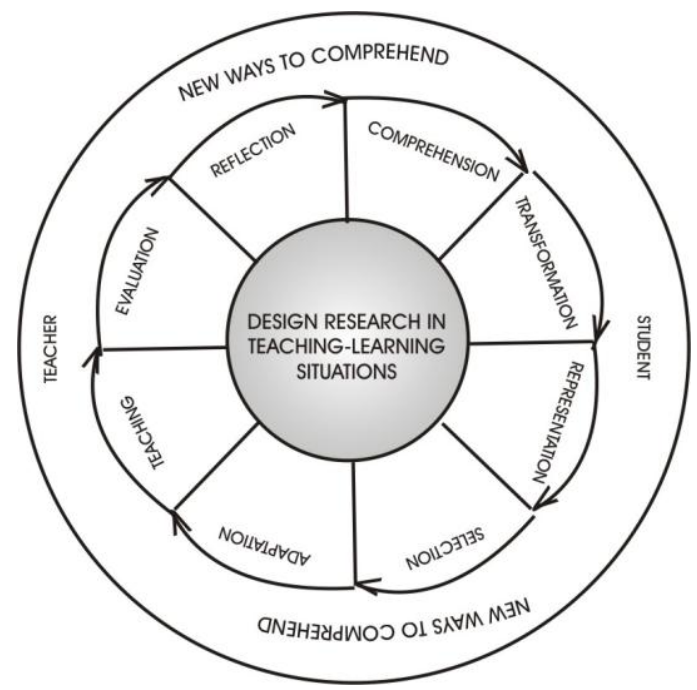

Figure 4. Reasoning Model for Analyzing Projects within the Scope of the Design in Situations of Teaching-Learning Line of Research Using the Multi-Tracks Project Proposed by Portugal (2009).

Comprehension: Multi-Tracks aims at helping in the acquisition of a second language. Besides its concrete and multimedia support, the game has a variety of components the teacher can use to achieve several objectives he wants to reach; for such, he should prepare, interpret and conduct a critical analysis of the material, understand the relationship of diverse components of the game such as the relation between the polygonal pieces and the cards, the functions of the cards, how to play etc. The game comes with a manual to facilitate an understanding of the diverse components and their use.

Transformation: The Multi-Tracks components can be transformed according to each class's or each school's program content. The teacher has the possibility to create new objects about themes, content he intends to teach, and for such he must prepare, interpret and conduct a critical analysis of the material. The teacher's function is to promote the student's experiences and actively assist in the knowledge construction process.

Representation: In Multi-Tracks, besides having a vast repertoire of representations which include analogies, metaphors, examples, demonstrations, explanations and etc., the teacher can also resort to diverse resources to represent his teaching-learning objectives and the child can represent the proposed tasks in several manner like using Brazilian sign language (LIBRAS), Portuguese, typing, drawings, mimic, etc. This enables a very big flow of information in the teaching-learning process through elements of design. We can see that learning occurs from inside out in children. The students get involved physically and mentally with the activities and feel motivated through them. 


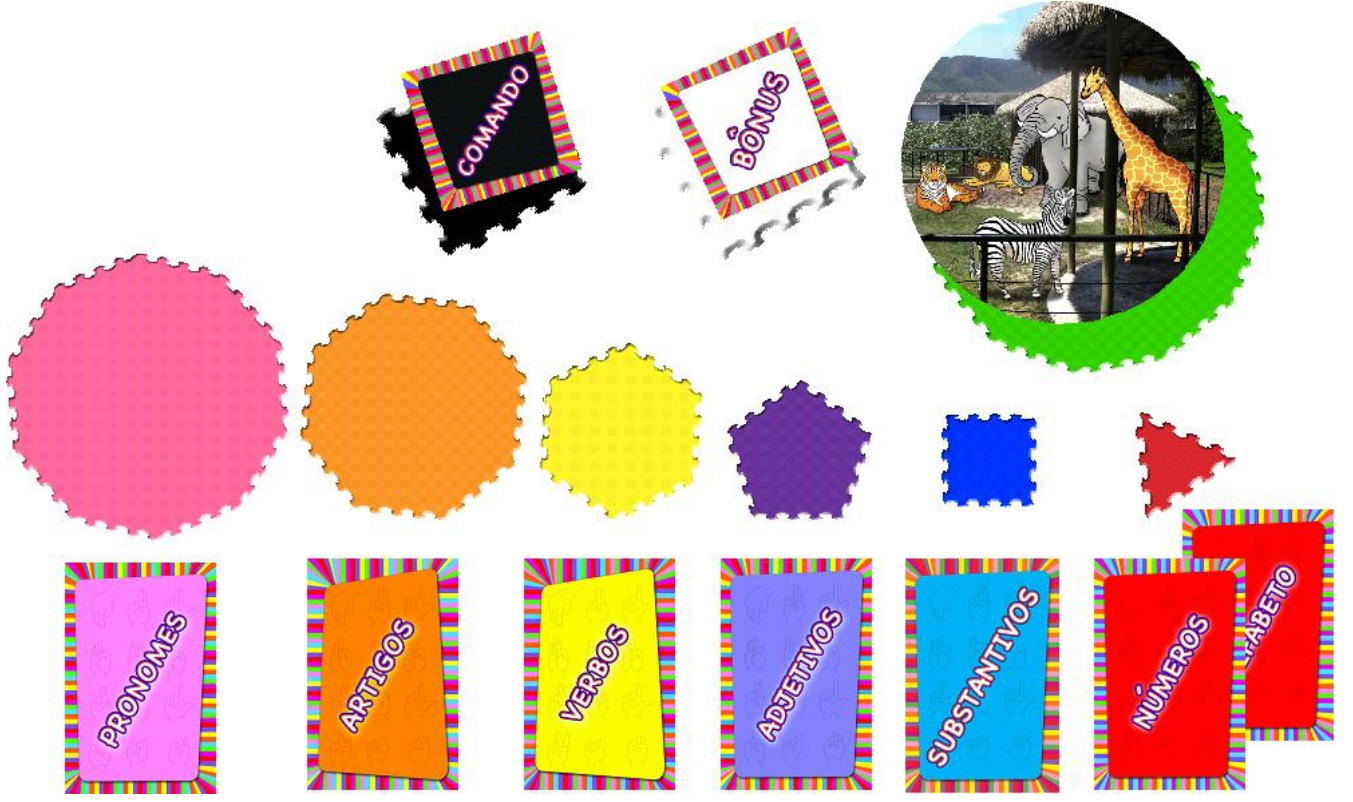

Figure 5. Polygonal Pieces and the Game's Cards

Selection: Multi-Tracks offers the teacher the chance to choose from a didactic repertoire that includes modalities of teaching, management, and organization. The game components include the polygonal pieces, cards and scenarios, which can be selected in accordance with the class objective. For example, if the teacher wants to teach verbs and adjectives, he can select the polygonal pieces and the cards that refer to the purpose he wants to achieve.

Adaptation and Adjustment of Students' Characteristics: Multi-Tracks has the city of Rio de Janeiro as its context. Its scenarios include the Pão de Açucar, the Zoo and the Fire Department. The bonus cards address three themes; means of transportation, food, and clothing. The teacher can resort to these resources or make adaptations and adjustments in accordance with student characteristics. It offers the possibility to consider concepts and prejudice, wrong concepts, difficulties, language, culture and motivations, social class, age, capacity, aptitude, interest, concept of oneself and attention.

Teaching: Multi-Tracks is a rich educational material that offers the teacher several ways to teach. Through its components, the teacher can make manipulations, presentations, interactions, group work, humor, discipline, question formulation and other aspects of active teaching, instruction for discovery and/or enquiry, as well as forms of teaching observed in the classroom. It also promotes the interaction of deaf and hearing children by constructing the environment as they interfere in it, conduct their activities, play and construct knowledge.

Evaluation: During and after playing Multi-Tracks, the teacher shall conduct an evaluation of the students' learning process. He can thus evaluate his own performance and adapt to the experiences. The teacher can verify student understanding during interactive teaching, evaluate student comprehension upon finalizing lessons or units.

Reflection: Multi-Tracks is complex material that has many components and if used properly it becomes necessary to revise, reconstruct, represent and critically analyze the performance of the teacher and the class and student, and to base the explanations on evidence. 

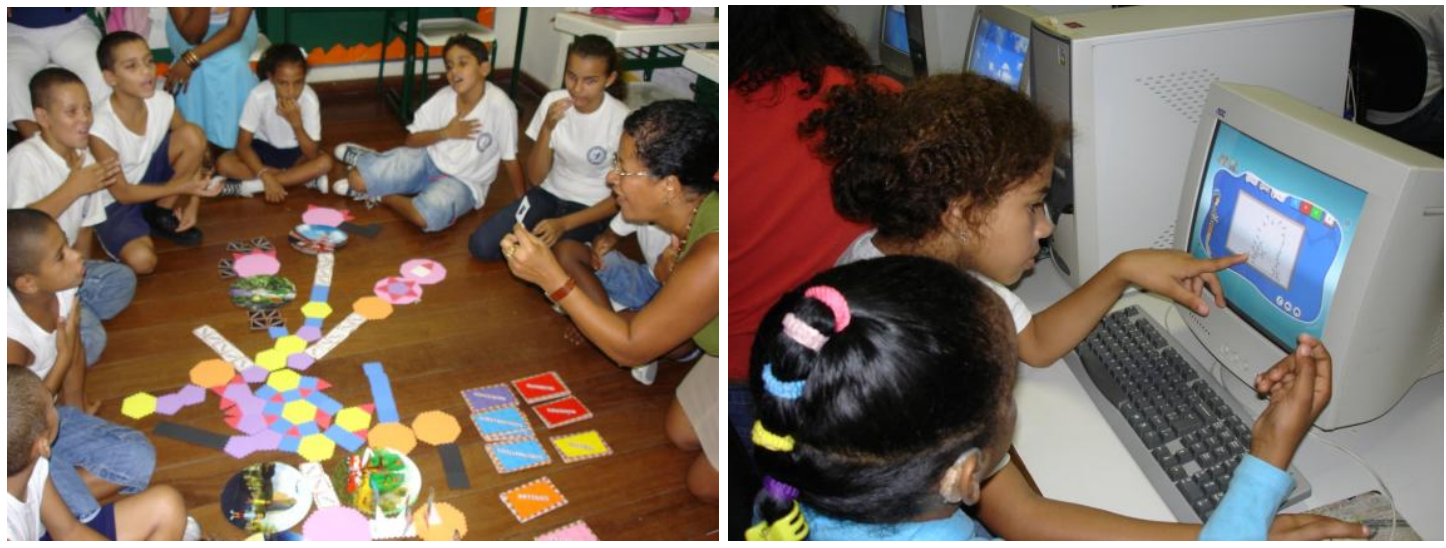

Figure 6: The Concrete and the Multimedia Multi-Tracks Game Used in the Classroom with Deaf Children

New Ways to Comprehend: The use of Multi-Tracks in the teaching-learning process helps the teacher comprehend new forms of teaching. It can consolidate new modes of understanding and learning. It offers the teacher a new form of understanding objectives, content, students, teaching and himself.

Multi-Tracks game enables teaching diverse pedagogical content and in diverse ways, not only due to its concrete and multimedia support but also, as we addressed previously, due to its aspects that are common to both objects.

The model of pedagogical reasoning and action proposed by Shulman (2008), on which we based ourselves to present Multi-Tracks as a project in the Design in Situations of TeachingLearning line of research, emphasizes the intellectual basis for faculty performance and not only teacher conduct. The author affirms that if one intends to take this idea seriously, it is indispensable to revise teaching as well as the content of teacher training programs. These programs can no longer restrict their activities to didactics and to supervision alone but also on the formation of teacher capacity to reflect on teaching and to teach specific subjects as well as his capacity to base actions on premises that resist complete analysis from the professional community.

The adoption of this perspective gains is strengthened with Kramer's (1997) statement which considers a new proposal for education as a bet.

"A new proposal for education; a new curriculum is an invitation, a challenge, a bet. A bet because, as part of a given public policy, it contains a political project for society and a concept of citizenship, of education and of culture. Therefore, one cannot bring ready-made answers just to be implemented if one aims at contributing towards the construction of a democratic society where social justice is indeed an equally distributed asset to all. A pedagogical proposal always expresses the values of which it is comprised and it needs to be closely tied to the reality on which it focuses, explaining its objectives of critically thinking of this reality, and confronting it most acute problems. A pedagogical proposal must be constructed with the actual participation of all subjects - children and adults, students, teachers and non-faculty professionals, families and the population in general - taking into consideration their needs, 
specificities and reality. This also points to the impossibility of a single proposal, since reality is multiple and contradictory" (Kramer, 1997, p. 21).

Closely echoing the ideas of Shulman and Kramer, we resort to Efland et al. (2003) when they affirm that the path that awaits us is uncertain and the ante high. According to these authors, if we could successfully apply a post-modern focus on artistic education and we could include design here, general knowledge of cultural diversity would fill the vacuum left behind mere isolated data presented in the teacher formation process and designers. An education constructed from multiple perspectives foments critical thought, acceptance and tolerance of difference. It also provides an exercise in democratic action and a re-evaluation of our ecological, educational, and social responsibilities.

\section{Conclusions}

Throughout the elaboration of this project, through an interdisciplinary dialogue between design and education, we sought to identify how design activity could participate in teachinglearning processes and in the configuration of pedagogical materials, with the objective of enhancing the knowledge acquisition process through the configuration of artifacts, environments, and analog and digital systems.

The Design in Situations of Teaching-Learning line of research served as a basis to expand knowledge of the relationship between the two main areas involved. It was defined as an area preferably inserted in the academic field and that agglutinates works where there is designer participation in projects geared towards education at any level - nursery, elementary, high school, university and advanced - as well as for studies and research related to the teaching of design in the extra-university, technical, extension, undergraduate, and graduate ambits. Its basic principle is to enhance the knowledge construction process. In this perspective, each design solution represents the search for equilibrium between interests and needs of the teacher and student as well as of educational institutions.

Through this project, we sought to create subsidies for planning educational materials from a multiple perspective, which observes the educational specificities and its dialogue as well as the transit with neighboring reality, aimed at the creation of more productive and interactive teaching-learning processes.

The option of using an artifact developed in light of design as the object of work, registering and discussing its configuration process and the experience that took place in its development process was decisive for understanding the diverse issues involved in a Design in Situations of Teaching-Learning project.

We also verify that the practice of Design in Situations of Teaching-Learning enables designers to deal with complex problems. In this particular point, the formation of interdisciplinary teams is indispensable since they provide for the creation of efficient educational artifacts, promoting and sustaining educational relations, providing dialogue between the teacher and student in the teaching-learning process. Educational technology research in special education is rather weak so this work may contribute to this field.

The more in-depth theoretical study conducted on teaching-learning issues helped us, guided by Shulman's ideas, to understand that to obtain results in the teaching process it is necessary 
and obligatory for it to be conceived as an activity that implies joint work between teachers and students. This work implies exercising thought as well as action by all players.

The proposal for a pedagogical reasoning and action model to analyze projects within the scope of the Design in Situations of Teaching-Learning line of research was conceived using the Multi-Tracks Project as a case study. This led to the conclusion that the application of design methods and techniques in objects directed towards teaching deaf children to read and write. may not only help make this task more productive and pleasant but also contribute towards delimiting a multidisciplinary field comprised of design, education, art, psycho-pedagogy, information technology etc.

From this development work, it was possible to create an outline for a Design in Situations of Teaching-Learning methodology comprised of cyclical actions where the steps of the methodology; that is, information, experience, data, evaluations, decisions, conclusions, etc. are in interactive movement, being covered for understanding, fitness, and development of the project one intends to carry out.

\section{References}

Bonsiepe, G. (2011). Design, cultura e sociedade. São Paulo: Edgar Blucher.

Bruner, J. (2006). Actos de significado. Más allá de la revolución cognitiva. Madrid: Editorial Alianza.

Buxton, B. (2007). Sketching user experiences: Getting the design right and the right design. São Francisco: Morgan Kaufman.

Capra, F. (1994). Pertencendo ao universo: explorações nas fronteiras da ciência e da espiritualidade. São Paulo: Cultrix.

Couto, R. (2009). Desenvolvimento de ilustrações de movimentos da Língua de Sinais Brasileira-LIBRAS. 4o Congresso Internacional de Design da Informação \& 3 InfoDesign Brasil. Rio de Janeiro: PUC-Rio.

Efland, A. D., Freedman, K. E., \& Stuhr, P. (2003). Educación y el arte posmoderno. Barcelona: Paidos.

Engelhardt, Y. (2002). The language of graphics: A framework for the analysis of the syntax and meaning in maps, charts and diagrams. Amsterdam: Illc-publications.

Fontoura, A. (2002). EdaDe - Educação de crianças e jovens através do design (Tese Doutorado em Engenharia da Produção). Programa de Pós-Graduação em Engenharia da Produção, Santa Catarina: UFSC.

Frascara, J., Meurer, B., Toorn, J., Winckler, D. (1997). User-centred graphic design: Mass communication and social change. Boca Raton, FL: CRC Press.

Freedman, K. (2003). Teaching visual culture. New York: Columbia University Teachers College Press.

Kramer, S. (1997). Propostas pedagógicas ou curriculares: Subsídios para uma leitura crítica. Educação \& Sociedade, ano XVIII, no 60.

Upton, E. \& Phillips, J. ( 2009). Novos fundamentos do design. São Paulo: Cosac Naify. 
Mitchell, W. (2005). What do pictures want? The lives and loves of images. Chicago: University Of Chicago Press.

Moggidge, B. (2007). Designing interaction. Cambridge, MA: MIT Press.

Portugal, C., Couto, R., Ribeiro, F. (2011). Image in the knowledge construction. Design Principles and Practices: An International Journal, 5(3), 327-336.

Portugal, C. (2009). Design em Situações de Ensino-aprendizagem. Um diálogo Interdisciplinar. (Tese Doutorado em Design ). Departamento de Artes \& Design. Pontifícia Universidade Católica do Rio de Janeiro, Rio de Janeiro.

Shulman, L. S. (1996). Paradigmas y programas de investigación en el estudio de la enseñanza: una perspectiva contemporánea. En M. C. Wittrock(Ed.), La Investigación de la Enseñanza, I. Enfoques, Teorías y Métodos, Barcelona: Paidós.

Shulman, L. S. (2008). Conocimiento y enseñanza: Fundamentos de la nueva reforma. Retrieved 20 January 2011 from http://www.ugr.es/local/recfpro/Rev92ART1.pdf.

Rollings A. \& Morris D. (2004). Game architecture and design: A new edition. Indianapolis, IN: New Riders Publishers.

Sacks, O. (1999). Seeing voices: A journey into the world of the deaf. Berkeley, CA: University of California Press.

Sommerman, A. (2006). Inter e transdiciplinaridade? Da fragmentação interdisciplinar ao no diálogo entre os saberes. São Paulo: Paulos.

Spence, R. (2007). Information visualization: Design for interaction. Englewood Cliffs, NJ: Prentice Hall.

Wanderley, R. (2006). Uma abordagem para a representação gráfica de 'ações dinâmicas'. (Dissertação de mestrado). Departamento de pós-graduação em Design, Universidade Federal de Pernambuco.

Correspondence: Cristina Portugal, Ph.D., Departament of Arts and Design, Pontifical Catholic University of Rio de Janeiro, Brazil 